\title{
ALPHA-AMINOISOBUTYRIC ACID UPTAKE IN PRIMARY CULTURES OF ASTROCYTES
}

\author{
C. J. Cummins, ${ }^{1,3,4}$ R. A. Glover, ${ }^{2}$ and O. Z. Sellinger ${ }^{3}$ \\ 'Surgical Neurology Branch
}

National Institute of Neurological and Communicative

Disorders and Stroke

National Institutes of Health

Bethesda, Maryland 20205

${ }^{2}$ Department of Anatomy and Cell Biology

The University of Michigan School of Medicine

Ann Arbor, Michigan 48109

${ }^{3}$ Mental Health Research Institute

The University of Michigan School of Medicine

Ann Arbor, Michigan 48109

Accepted August 23, 1982

\begin{abstract}
Homotypically pure cultures of rat brain astrocytes were used to examine some aspects of non-neuronal A-system (alanine preferring) amino acid uptake. The Asystem specific probe, alpha-aminoisobutyric acid is transported rapidly, and a steady state distribution ratio of $9-25$ is reached after 30 minute incubations. Kinetic estimates derived from uptake progress curves indicated a $K_{m}$ of $1.35 \mathrm{mM}$ and a $V_{\max }$ of $133 \mathrm{nmol} / \mathrm{min} / \mathrm{mg}$ protein. Uptake is reduced in the absence of either $\mathrm{Na}^{+}$or $\mathrm{K}^{+}$. Elevations in extracellular $\mathrm{K}^{+}$, a putative metabolic modulator of neuroglia, did not affect uptake.
\end{abstract}

\section{INTRODUCTION}

The amino acids of brain function as energy sources, putative neurotransmitters, precursors of proteins and small peptides, and allosteric regulators of metabolic flux. The uptake of amino acids in brain may also play an important role in maintaining pools of precursors for synthetic path-

\footnotetext{
4 To whom all correspondence may be sent: 10A/3E68 SNB, NINCDS, NIH Bethesda, Maryland 20205 (301)-496-5728.
} 
ways, regulating metabolism, and in terminating the effects of putative amino acid neurotransmitters.

Brain appears similar to other tissues in that amino acids are accumulated against a concentration gradient and transport systems discriminate between classes of amino acids on the basis of structural features $(1,2,12,15)$.

Since brain is a highly heterogeneous tissue, the role of specific cell types in any process may be difficult to ascertain. Thus, we were interested to determine the uptake properties of amino acids in primary cultures of rat brain astrocytes. Astrocytes actively transport amino acids $(7,9,14)$. Alpha aminoisobutyrate (AIB) is an unmetabolized amino acid analog, transported by the alanine-preferring (or A) amino acid transport system (12). We detail here the properties of ionic dependence, and the effects of extracellular $\mathrm{K}^{+}$on the astrocytic uptake of AIB.

\section{EXPERIMENTAL PROCEDURE}

Radiolabeled alpha- $\left[\right.$ methyl $\left.{ }^{3} \mathrm{H}\right]$ aminoisobutyric acid, specific activity $10 \mathrm{mCi} / \mathrm{mmol}$, was obtained from New England Nuclear, Boston, Mass.

Astrocytes were grown in culture as previously described (3). Confluent cultures are homotypically pure by histochemical staining (3). Cultures were used at confluence (12-14 days after seeding), forty-eight hours following the last feeding.

The buffer used throughout these experiments contained $5.3 \mathrm{mM} \mathrm{KCl}, 150 \mathrm{mM} \mathrm{NaCl}, 1$ $\mathrm{mM} \mathrm{CaCl}, 600 \mu \mathrm{M} \mathrm{MgCl}_{2}, 1.6 \mathrm{mM} \mathrm{KH}_{2} \mathrm{PO}_{4}$, and $4.3 \mathrm{mM} \mathrm{Na} \mathrm{HPO}_{4}, \mathrm{pH}$ 7.2. When the ionic composition of the buffer was varied, $\mathrm{Na}^{+}$was iso-osmotically substituted for $\mathrm{K}^{+}$.

To determine amino acid uptake, $60 \times 15 \mathrm{~mm}$ dishes of confluent astrocytes ( $10^{4}$ cells) were washed free of medium with $5-7 \mathrm{ml}$ of $37^{\circ} \mathrm{C} 0.9 \% \mathrm{NaCl}$ solution. The rims of the dishes were blotted, and two $\mathrm{ml}$ of buffer containing the appropriate concentration of $\mathrm{K}^{+}, \mathrm{Na}^{+}$, and radiolabeled amino acid were added.

The plates were returned to the incubator at $37^{\circ} \mathrm{C}$, or for incubations shorter than $5 \mathrm{~min}$, dishes were floated in a $37^{\circ} \mathrm{C}$ waterbath. At the appropriate time, the incubation medium was aspirated, and the dishes were rapidly rinsed in ice cold isotonic saline $(15-18 \mathrm{ml})$, and the edges were again blotted. Two $\mathrm{ml}$ of $0.2 \mathrm{M}$ perchloric acid were added, and the dishes were stored at $4^{\circ} \mathrm{C}$ overnight. The perchloric acid soluble fraction was removed, neutralized and duplicate or triplicate aliquots were counted.

Protein was determined by the procedure of Lowry et al. (13).

\section{RESULTS}

For the purposes of calculating the distribution ratio of AIB uptake ([intracellular]/[extracellular]) cell protein was assumed to constitute 10\%, and water to constitute $80 \%$ of the wet weight. Uptake indicated as per 


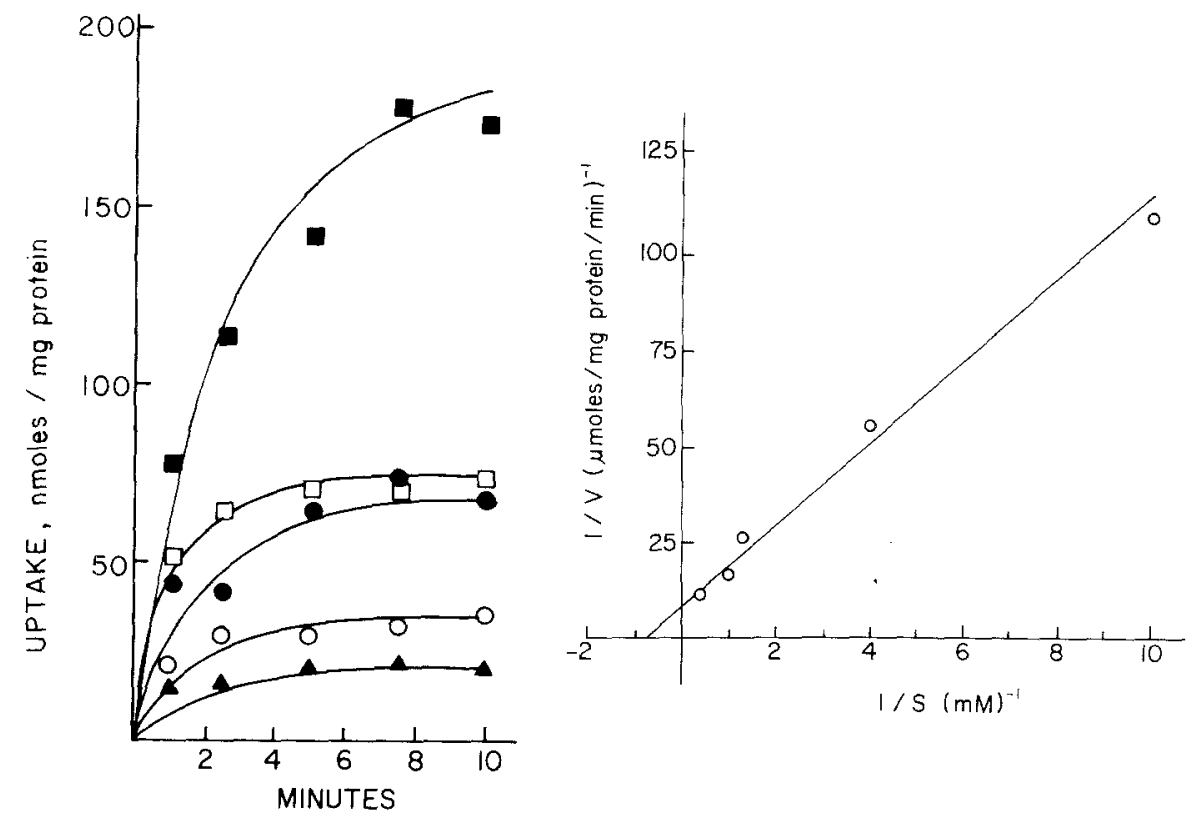

FIG. 1. The time course of alpha aminoisobutyrate uptake is shown for several AIB concentrations: $0.1 \mathrm{mM},(\Delta) ; 0.25 \mathrm{mM},(\bigcirc) ; 0.75 \mathrm{mM},(\bullet) ; 1.0 \mathrm{mM},(\square)$; and $2.5 \mathrm{mM},(\mathbb{E})$. Uptake is complete for most AlB concentrations by 2.5 minutes. B. The initial velocities of uptake in A were extrapolated as a tangent to the progress curve and are plotted according to the method of Lineweaver-Burk. The apparent $K_{m}$ is $1.35 \mathrm{mM}$, and the $V_{\max }$ is $133 \mathrm{nmol} /$ $\mathrm{min} / \mathrm{mg}$ protein. Each point represents the mean of duplicate determinations on 3-5 dishes, and the standard error was less than $15 \%$ of the mean.

mg protein is considered to be equivalent to uptake per $8 \mu$ l of cell water. AIB is assumed to be dispersed in the pool of intracellular water.

The time course of uptake of 0.1-2.5 mM AIB is shown in Figure 1. The Lineweaver-Burk plot of initial velocities (extrapolated from the progress curves of Figure 1) indicated an apparent $K_{m}$ of $1.35 \mathrm{mM}$, and a maximum velocity of $133 \mathrm{nmol} / \mathrm{mg} / \mathrm{min}$. The $K_{m}$ is close to that reported for Ehrlich ascites cells but the $V_{\max }$ is only about $10 \%(10,11)$.

Steady state distribution ratios (measured after 30 minute incubations) are 25 for $0.1 \mathrm{mM}$ extracellular AIB, and 9.0 for $2.5 \mathrm{mM}$ extracellular alpha-AIB (Table I). These values are similar to the data of Hamberger (8) who reported a distribution ratio of 4.0 for a 30 minute incubation with $0.1 \mathrm{mM}$ AIB in bulk isolated glia, and within the range of those reported by Lahiri and Lajtha (12) and Blasberg and Lajtha (1).

To determine the ionic dependence of AIB uptake, cultures were incubated in buffer containing various concentrations of AIB, $\mathrm{K}^{+}$and/or 
TABLE I

Alpha-Aminoisobutyric Acid Steady State Distribution Ratios

\begin{tabular}{ccc}
\hline $\begin{array}{c}\text { [Extracellular] } \\
\mathrm{mM}\end{array}$ & $\begin{array}{c}\text { [Intracellular] } \\
\mathrm{mM}\end{array}$ & Distribution Ratio \\
\hline 0.1 & 2.5 & 25 \\
0.25 & 3.13 & 12.5 \\
0.75 & 7.5 & 10.5 \\
1.0 & 8.75 & 8.75 \\
2.5 & 22.5 & 9.0 \\
\hline
\end{tabular}

Distribution ratios were determined for $\mathrm{AIB}$ in 30 minute incubations.

Intracellular water was assumed to be $8 \mu \mathrm{l} / \mathrm{mg}$ protein.

$\mathrm{Na}^{+}$. Table II shows the intracellular concentration of AIB at 30 minutes in the presence or absence of $\mathrm{Na}^{+}$or $\mathrm{K}^{+}$, or in the presence of elevated extracellular $\mathrm{K}^{+}$. Transport of AIB is reduced in the absence of either $\mathrm{K}^{+}$or $\mathrm{Na}^{+}$, indicating a dependence of transport on both cations. The observed $\mathrm{Na}^{+}$dependence is in agreement with observations of A system amino acids in Ehrlich ascites cells $(10,11)$ and in brain slices $(10-12)$.

\section{TABLE II}

Alpha-Aminoisobutyric Acid Uptake as a Function of the Concentration of Extracellular $\mathrm{K}^{+}$and $\mathrm{N}_{\mathrm{A}}^{+}$

\begin{tabular}{|c|c|c|c|c|c|}
\hline \multicolumn{6}{|c|}{ Alpha-Aminoisobutyrate Concentration (mM) } \\
\hline$\left[\mathrm{K}^{+}\right]$ & 0.1 & 0.25 & 0.50 & 1.0 & 22.5 \\
\hline$(\mathrm{mM})$ & \multicolumn{5}{|c|}{$\begin{array}{l}\text { AIB Uptake } \\
\text { nmol transported in } 30 \text { min per mg protein }\end{array}$} \\
\hline \multirow[t]{2}{*}{0} & 8.91 & 26.43 & 43.82 & 74.53 & N.D. \\
\hline & \pm 0.43 & \pm 1.46 & \pm 0.37 & \pm 3.12 & \\
\hline \multirow[t]{2}{*}{6.9} & 13.82 & 35.44 & 66.20 & 111.11 & 243.24 \\
\hline & \pm 0.32 & \pm 1.51 & \pm 2.04 & \pm 6.24 & \pm 9.44 \\
\hline \multirow[t]{2}{*}{11.9} & 21.75 & 42.10 & 64.75 & 103.4 & 247.34 \\
\hline & \pm 0.04 & \pm 1.95 & \pm 1.50 & \pm 3.22 & \pm 15.10 \\
\hline \multirow[t]{2}{*}{26.9} & 18.90 & 33.15 & 55.14 & 119.65 & 254.66 \\
\hline & \pm 2.09 & \pm 1.58 & \pm 3.06 & \pm 10.00 & \pm 15.34 \\
\hline 163.9 & 6.13 & 22.22 & 30.75 & 62.93 & N.D. \\
\hline$(-\mathrm{Na}+)$ & \pm 0.79 & \pm 2.02 & \pm 1.34 & \pm 4.84 & \\
\hline
\end{tabular}

The mean \pm SEM steady state levels of AIB are shown after 30 minute incubations as a function of the extracellular concentrations of both AIB and $\mathrm{K}^{+}$. (N.D. not done). Means are from duplicate determinations on 3-5 dishes. $\mathrm{K}^{+}$replaced $\mathrm{Na}^{+}$on an iso-osmotic basis except at $\left[\mathrm{K}^{+}\right]=163.9$, where $\mathrm{Na}^{+}$was omitted altogether. 
The active transport of AIB is not consistently altered by coincubation with elevated levels of extracellular $\mathrm{K}^{+}$.

\section{DISCUSSION}

AIB is a synthetic neutral amino acid which is rapidly taken up and concentrated by most cells. Its transport properties have been widely studied in nervous tissue. In brain AIB is transported by the A (or alanine preferring) system, which is characterized by $\mathrm{Na}^{+}$dependence and $\mathrm{Na}^{+}$ co-transport, and weak hetero- and homoexchange (10-12).

The active transport of AIB was reduced in the absence of extracellular $\mathrm{K}^{+}$or $\mathrm{Na}^{+}$, but the transport was independent of the specific concentration of extracellular $\mathrm{K}^{+}$. This is in distinction to the active transport of the leucine preferring (or L) system amino acid methionine, the uptake of which is increased by coincubation with elevated extracellular concentrations of $\mathrm{K}^{+}$(4-6). Cultivated rat brain astrocytes concentrate AIB 9-25 fold. Our observations suggest that (a) distinct transport systems may be regulated by different physiological mechanisms; and (b) typical features of brain transport systems are also seen in cultured glia and, perhaps, in glia in situ.

\section{REFERENCES}

1. Blasberg, R., and Lajtha, A. 1966. Heterogeneity of the mediated transport systems of amino acid uptake in brain. Brain Res. 1:86-104.

2. Christensen, H. 1969. Some special kinetic problems of transport, Pages 1-35, in F. F. Nord (ed.), Advances in Enzymology Vol. 32, Interscience Press, N.Y.

3. Cummins, C. J., and Glover, R. A. 1978. Propagation and histological characterization of a homotypic population of astrocytes derived from neonatal rat brain. J. Anat. (L) 125:117-125.

4. Cummins, C. J., Glover, R. A., and Sellinger, O. Z. 1979. Neuronal cues regulate uptake in cultured astrocytes. Brain Res. 170:190-193.

5. Cummins, C. J., Glover, R. A., and Sellinger, O. Z. 1979. Astrocyte uptake is modulated by extracellular $\mathrm{K}^{+}$. J. Neurochem. 33:779-785.

6. Cummins, C. J., Glover, R. A., and Sellinger, O. Z. 1982. Potassium modulation of methionine uptake in astrocytes in vitro. Neurochem. Res., 7:637-644.

7. Haber, B., Suddith, R. L., Pacheco, M., Gonzales, A., Ritchie, T. L., and GlusMAN, S. 1978. Model systems for the glial transport of biogenic amines and GABA: clonal cell lines and the filum terminale of the frog spinal cord, Pages 193-206, in ScHOFfeniels, E., Franck, G., Tower, D. B., and Hertz, L. (eds) Dynamic Properties of Glia Cells, Pergamon Press, N.Y.

8. Hamberger, A. 1971. Amino acid uptake in neuronal and glial cell fractions from rabbit cerebral cortex. Brain Res. 31:169-178.

9. Hamberger, A., Cotman, C. W., Sellstrom, A., and Weiler, C. T. 1978. Glutamine, 
glial cells and their relationship to transmitter glutamate, Pages 153-172, in SchofFENiels, E., Franck, G., Tower, D., and Hertz, L., (eds), in Dynamic Properties of Glia Cells, Pergamon Press, N.Y.

10. JACQuez, J. 1973. Sodium dependence of maximum flux, Jm, and $\mathrm{Km}$ of amino acid transport in Erhlich ascites cells. Biochim. Biophys. Acta 318:411-425.

11. JACQUez, J., Sherman, J. and Terris, J, 1970. Temperature dependence of amino acid transport in Erhlich ascites cells; with results that bear on the A-L distinction. Biochim. Biophys. Acta 203:150-166.

12. Lahiri, S. and Lajtha, A. 1964. Cerebral amino acid transport in vitro I; some requirements and properties of uptake. J. Neurochem. 11:77-86.

13. Lowry, O. H., Rosebrough, N., Farr, A. and Randall, R, 1951. Protein measurement with the Folin phenol reagent. J. Biol. Chem. 193:265-275.

14. Schousboe, A. 1978. Glutamate, GABA and taurine in cultured, normal glia cells, Pages 173-182, Schoffeniels, E., Franck, G., Tower, D. B., and Hertz, L. (eds), Dynamic Properties of Glia Cells, Pergamon Press, N.Y.

15. Sershen, H., and Lajtha, A. 1979. Inhibition pattern by analogs indicates the presence of ten or more transport systems for amino acids in brain cells. J. Neurochem. 32:719726. 